\title{
Tinjauan Juridis Perkembangan Tanah-Tanah Adat (Dahulu, Kini dan Akan Datang)
}

\author{
Novyta Uktolseja ${ }^{1}$ \\ Pieter Radjawane ${ }^{2}$ \\ ${ }^{1}$ Fakultas Hukum Universitas Pattimura. Ambon, Indonesia \\ E-mail:nuktolseja@yahoo.co.id \\ ${ }^{2}$ Fakultas Hukum Universitas Pattimura. Ambon, Indonesia \\ E-mail: pietraradja@gmail.com
}

\begin{abstract}
Regarding land acquisition by humans (land tenure), Indonesia has its own history of the occurrence of various complex land tenure categories. Each land tenure category each has a characteristic setting regarding land ownership and ownership, and management objectives. This can be seen in Indonesian society in each area of residence other than the Indonesian people, the land also affects the government which in this case the government has the authority to control the land in use and intended for the community but the fact that the community is at a disadvantage by the government. thus how is the development of customary land which in the past was not registered, then in the present many customary land must be registered if registered so that the status of the land that was originally customary land changed status to property rights, then how to protect land adat which does not register what the impact of these lands will be in the future.
\end{abstract}

Keywords: Land, Customary Law.

\section{A. PENDAHULUAN.}

Tanah merupakan sumber kehidupan bagi manusia, dengan tanah manusia dapat berpijak dalam melakukan semua aktifitasnya sehari-hari, dan seperti kita ketahui bahwa pada kenyataannya tanah adalah benda mati akan tetapi mempunyai sumber nilai dan manfaat yang sangat signifikan bagi seluruh umat manusia yang ada di muka bumi ini.

Tanah juga merupakan faktor terpenting bukan saja di saat manusia masih hidup tetapi disaat manusia meninggal dunia, membutuhkan tanah sebagai tempat peristirahatan yang terakhir. Pentingnya arti tanah bagi kehidupan manusia adalah bahwa 
kehidupan manusia sama sekali tidak bisa dipisahkan dari tanah. Mereka hidup di atas tanah dan memperoleh bahan pangan dengan cara mendayagunakan tanah. ${ }^{1}$

Hal ini dapat di lihat dalam kehidupan masyarakt Indonesia pada masing-masing wilayah tempat tinggal dan selain pada masyarakat Indonesia, tanah juga berdampak pada pemerintah yang dalam hal ini pemerintah mempunyai kewenangan untuk menguasai tanah di pergunakan dan diperuntukan pada masyarakat tapi kenyataan yang terjadi masyarakat banyak di rugikan oleh pemerintah.

Sebagaimana yang sudah di jelakan diatas, maka keberadaan kehidupan masyarakat dengan tanah merupakan suatu hubungan antara tanah dan penguasanya, dalam hal ini adalah masyarakat hukum adat, dalam kehidupan sehari-hari menjalankan aktifitas mereka berdasarkan aturan dan norma yang berbeda-beda sesuai dengan adat tradisi yang dianut oleh masing-masing masyarakt hukum adat yang terpencar pencar di seluruh belahan jiwa bangsa Indonesia.

Menurut J.B.A.F. Polak, bahwa hubungan manusia dengan tanah sepanjang sejarah terjadi dalam 3 (tiga) tahap berikut ini. ${ }^{2}$ Yaitu :

1. Tahap pertama, yaitu tahap di mana manusia memperoleh kehidupannya dengan cara memburu binatang, mencari buah-buahan hasil hutan, mecari ikan di sungai atau di danau. Mereka hidup tergantung dari persediaan hutan, mereka hidup mengembara dari tempat yang satu ke tempat yang lain.

2. Tahap kedua, yaitu bahwa pada tahap ini manusia sudah mulai mengenal cara bercocok tanam. Manusia mulai menetap di suatu

${ }^{1}$. Muhibbin, Moh. (2011). Penguasaan atas tanah timbul ( aanslibbing ) oleh masyarakat dalam perspektif hukum Agraria Nasional, Ringkasan Disertasi, Program Doktor Ilmu Hukum Fakultas Hukum Universitas Brawijaya, h. 1. tempat tertentu selama menunggu hasil tanaman. Ikatan terhadap tanahpun semakin erat oleh karena cara beternak yang dikenal manusia dan bersamaan dengan pengenalan cara bercocok tanam.

3. Tahap ketiga, yaitu tahap di mana manusia mulai menetap di tempat tertentu dan tidak ada lagi perpindahan peroidik. Manusia sudah mulai terikat pada penggunaan ternak untuk membantu usaha-usaha pertanian, untuk kelangsungan hidupnya sudah mulai dari hasil pertanian dan peternakan. Juga, pada tahap ini manusia mulai terjamin hidupnya dengan mengandalkan hasil - hasil pertanaian dan peternakan daripada hidup mengembara. Mulai juga merasakan adanya surplus hasilhasil produksi, corak pertanian, mengelola sendiri, menunggu hasil pertanian untuk jangka waktu yang lama, kemudian memungut hasilnya yang kemudian mendorong ke arah pemilikan tanah (individual), meskipun masih tunduk pada kehidupan persekutuan. Pada saat ini manusia mulai menetap dan mengenal pertukangan, terdapat surplus hasil pertanaian dan kerajinan pada kelompok hidup orang-orang yang telah menetap. Keadaan ini mendorong lahirnya kelompok orang-orang yang mulai mengkhususkan dirinya sebagai penjaga keamanan dan melindungi masyarakat dari gangguan keamanan dari perampok.

Berdasarkan tahap-tahap hubungan manusia dengan tanah yang dikemukakan oleh J.B.A.F. Polak tersebut, dapat dikemukan bahwa hubungan manusia

2 Soeprapto, R. (1966). Undang-Undang Agraria Dalam Praktek, Jakarta, Mitra Sari, h. 36. 
dengan tanah pada awalnya adalah pendudukan sebagai dasar usaha untuk menjadi sumber Penghidupannya. Kemudian berkembang pengurusan yang berkaitan dengan pemanfaatannya, dan akhirnya berkembang kepada penguasaan atas tanah. Dengan berkembangnya penduduk, kebutuhan tanah semakin luas yang dikuasai. ${ }^{3}$

Selain mempunya arti yang sangat penting bagi manusia, tanah juga mempunyai kedudukan yang penting bagi kehidupan masyarakat hukum adat secara komunal maupun secara individu, Hukum adat mengenal adanya 2 (dua) hal yang menyebabkan tanah itu memiliki kedudukan yang sangat penting di dalam hukum adat yang disebabkan oleh:

1. Karena sifatnya, yang merupakan satu-satunya benda kekayaan yang meskipun mengalami keadaan yang bagaimanapun juga akan tetap masih bersifat tetap dalam keadaannya bahkan menjadi lebih menguntungkan

2. Karena faktanya, yaitu kenyataannya bahwa tanah itu adalah:
a. Merupakan tempat tinggal persekutuan (masyarakat)
b. Memberikan penghidupan kepada persekutuan (masyarakat)

c. Merupakan tempat dimana para warga persekutuan (masyarakat) yang meninggal dunia dikuburkan

d. Merupakan tempat tinggal bagi para danyang - danyang pelindung persekutuan (masyarakat) dan roh - roh para leluhur persekutuan (masyarakat).

3 Samosir, Djamanat. (2013). Hukum Adat Eksistensi Dalam Dinamika Perkembangan Hukum Di Indonesia, Cetakan I, Bandung: Nuansa Aulia, h. . 99-100.

${ }^{4}$ Koesnoe, H.Moh. (2002). Kapita Selekta Hukum Adat Suatu Pemikiran Baru, Varia Peradilan, Jakarta: IKAHI, h.. 6.
Berdasarkan uraian-uraian yang tersebut diatas dapat dijelaskan bahwa tanah dan masyarakat hukum adat yang berlaku sebelum kemerdekaan dan sebelum berlakunya Undang-undang Nomor 5 tahun 1960 tentang Peraturan Dasar Pokok Agraria (selanjutnya disebut UUPA) adalah tanah adat yang dikuasai berdasarkan pada adat-istiadat masyarakat persekutuan hukum adat baik secara komunal maupun secara individualitis dengan cara membuka hutan, yang merupakan hak manusia sebagai mahkluk sosial.

Persoalan tanah yang terjadi dalam kehidupan masyarakat hukum adat selama mereka masih hidup dalam wilayah yang dihakinya tidak terlepas dari adat-istiadat, hukum adat, persekutuan dan anggota persekutuan. Dalam sistim hukum yang dianut oleh Indonesia yaitu hukum tertulis (statuta law), Indonesia juga menganut hukum yang tidak tertulis (unstatuta law), yaitu hukum adat, menurut Koesnoe. 4 Adat adalah keseluruhan dari pada ajaran-ajaran dan amalannya yang mengatur cara hidup orang Indonesia didalam masyarakat, ajaran dan amalan mana langsung dilahirkan dari pada tanggapan rakyat, tentang manusia dan dunia, dalam hubungan ini adat adalah tatanan hidup rakyat Indonesia Indonesia yang bersumber pada pada rasa susilanya.

Selanjutnya pengertian hukum adat menurut Ter Haar Bzn. ${ }^{5}$ Adalah bahwa hukum adat lahir dari dan dipelihara oleh keputusan - keputusan, keputusan para warga masyarakat, terutama keputusan berwibawa dari kepala-kepala rakyat yang membantu pelaksanaan perbuatanperbuatan hukum, atau dalam pertentangan kepentingan keputusan para

5 Vollenhoven, C.Van, dalam Rato, Dominikus. (2011). Hukum Adat (Suatu Pengantar Singkat Memahami Hukum Adat Di Indonesia), Yogjakarta: Laksbang Pressindo, h. 13. 
hakim yang bertugas mengadili sengketa, sepanjang keputusan-keputusan itu, karena kesewenangan atau kurang pengertian, tidak bertentangan dengan keyakinan hukum rakyat, melainkan senapas seirama dengan kesadaran tersebut, diterima/diakui setidak-tidaknya ditoleransikan olehnya.

Dari pandangan yang dikemukan oleh para sarjana tersebut diatas dapat dilihat bahwa adat, hukum adat dan masyarakat hukum adat yang diakui secara tidak tertulis tersebut mempunyai konsep yang hanya dipahami dan diakui oleh masyarakat-masyarakat hukum adat itu sendiri, berbeda pandangan dengan pemerintah selaku pemegang kekuasaan tertinggi yang secara tertulis mengakui adat dan masyarakat hukum adat yang termuat dalam sumber-sumber hukum negara.

Selanjutnya adat adalah kebiasaan suatu masyarakat yang bersifat ajeng (dilakukan terus-menerus), dipertahankan oleh para pendukungnya. Kebiasaan merupakan cermin kepribadian suatu bangsa, ia adalah penjelmaan jiwa bangsa itu yang terus menerus berkembang secara evolusi dari abad ke abad, ${ }^{6}$. Pengertian adat yang merupakan konsep dasar dari timbulnya suatu kebiasaan, yang pada akhirnya menimbulkan suatu norma yang menjadikan suatu batasan-batasan yang harus di patuhi yaitu hukum, dengan konsep hukum maka dapat dikatakan bahwa adat-istiadat tidak terlepas dari namanya hukum.

\footnotetext{
${ }^{6}$ Perkembangannya itu ada yang cepat dan ada yang lamban. Secepat apapun perkembangannya, namun tidak bersifat revolusioner.karena perkembangan revolusioner bersifat membongkar hingga ke akar-akarnya. Perkembangan kebiasaan, walaupun cepat tetapi tidak membongkar semua akar kebudayaan bangsa itu, sebab di dalamnya terdapat nilai-nilai yang menjadi dasarnya. Perkembangan selalu dilandasi oleh nilai dasar yang menjadi pedoman mereka untuk mengubah, memperbaharui, atau menghilangkan sesuatu bagian dari kebiasaan itu jika kebiasaan itu sudah tidak berfungsi lagi.
}

Kebiasaan ini dibuat untuk dijadikan pedoman bagi anggota masyarakat berperilaku, dengan harapan apa yang menjadi tujuan hidup mereka tercapai, misalnya tujuan hidup mereka itu adalah ketentraman, keteraturan, ketertiban, kesejahteraan, kebaikan, jika kebiasaan itu demikian baik, mulia, sudah terwujud, maka dibutuhkan sarana yang lebih bersifat memaksa agar setiap anggota masyarakat menaati, mempertahankan dan melaksanakan, menjaga kelestariannya, yaitu hukum. ${ }^{7}$

Namun demikian, konsep adat juga merupakan keseluruhan dari pada ajaranajaran yang mengatur cara hidup orang Indonesia didalam masyarakat, ajaran dan amalan mana langsung dilahirkan dari pada tanggapan rakyat tentang manusia dan dunia, ${ }^{8}$.

Konsep kehidupan masyarakat di Indonesia memiliki pandanganpandangan mengenai hubungan manusia dengan tanahnya, demikian pula yang berkaitan dengan cara hidup pada manusia tersebut, hal demikian juga yang terjadi dalam kehidupan masyarakat di Maluku. Masyarakat di Maluku merupakan masyarakat adat yang terdiri dari kepulauan-kepulauan yang terbagi atas dua jazirah yaitu; Jazirah Hitu yang di sebut dengan belahan bagian Timur dan Jazirah Leitimor yang di sebut belahan bagian Barat, konsep kehidupan adat dalam masing-masing jazirah, Sangatlah berbeda-beda, di dalam masing-masing jazirah juga tergambar jelas bagaimana kehidupan masyarakat

Rato, Dominikus. (2011). Hukum adat (suatu pengantar singkat memahami hukum adat di Indonesia), Yogyakarta: Laksbang pressindo, h. 1

7 Hukum yang dibuat untuk memaksa agar setiap anggota masyarakat atau masyarakat itu sendiri menaati, mempertahankan,melaksanakan, menjaga kelestarian nilai budaya itu, diharapkan bersumber dan berlandaskan kebudayaan itu sendiri. Drngan demikian anggota masyarakat itu merasa ikut memiliki dan dengan demikian mereka akan mentaatinya dengan penuh kesadaran. Ibid, h. 2

${ }^{8}$ Koesno, H.Moh. Op. Cit., h.6. 
adat di dalam negeri-negeri atau klan-klan yang mayoritas beragama muslim dengan negeri-negeri yang mayoritas beragama Kristen.

Valerine. J. L. Kriekhhoff mengemukakan bahwa adanya keragaman ini tidak berarti bahwa tidak dijumpai adanya persamaan dalam kehidupan bersama di wilayah tersebut, oleh karena masih adanya latar belakang historis yang dimiliki bersama, pengakuan tentang adanya prinsip-prinsip pokok dalam system kekerabatan, dan dengan adanya norma-norma adat tertentu yang diakui bersama. ${ }^{9}$

Hal-hal mengenai konsep hukum adat dalam masyarakat Maluku, terutama mengenai konsep adat mempunyai dua pengertian yang secara umum itu dimaksudkan adalah sisa - sisa agama asli yang masih terdapat secara luas, khususnya pada sikap-sikap dan kebiasaan - kebiasaan yang berkaitan dengan kepercayaan pada arwah-arwah leluhur dan kekuatan-kekuatan gaib yang berhubungan dengan tempat-tempat dan obyek-obyek tertentu, dan lain-lain semacam itu. Pengertian kedua yang tercakup dalam istilah adat bersifat lebih khusus. ${ }^{10}$.

Berdasarkan uraian latar belakang diatas, maka permasalahannya adalah: Bagaimana Perkembangan Tanah-Tanah Adat Dahulu, Kini Dan Akan Datang, dan Bagaimana Perlindungan Hukum Bagi Masyarakat Hukum ?.

\section{B. METODE PENELITIAN}

Penelitian ini menggunakan penelitian hukum normatif. Pendekatan yang digunakan adalah pendekatan perundang - undangan, pendekatan konseptual,. Sesuai dengan sifat penelitian hukum normatif, maka sumber bahan

${ }^{9}$ Kriekhoff, Valerine Jaqueline Leonora. (1991). Kedudukan tanah dati sebagai tanah adat di Maluku Tengah suatu kajian dengan memanfaatkan pendekatan Antropologi Hukum, hukum yang digunakan yaitu bahan hukum primer dan bahan hukum sekunder. Dilakukan dengan menganalisa dan Analisa data dilakukan secara kualitatif mengingat data yang terkumpul bersifat deskriptif.

\section{PEMBAHASAN}

\section{Tanah Adat Dalam Perkembangannya.}

Tanah dari zaman dahulu hingga zaman yang akan datang sangat fenomenal, karena tanah merupakan kebutuhan investasi jangka panjang dan menjadi rebutan Pemerintah, swasta maupun masyarakat dari yang level rendah hingga masyarakat yang level tinggi, masyarakat lokal maupun non lokal, dengan demikian tanah adat yang selalu menjadi rebutan itu tidak memandang apakah itu tanah dengan hak milik, hak pakai ataupun tanah-tanah adat, hal-hal inilah yang selalu terjadi di dalam kehidupan masyarakat.

Berbicara mengenai tanah disini yang paling menonjol adalah mengenai tanah-tanah adat, Persoalan tanah adat terjadi karena kurangnya pemahaman masyarakat adat terhadap tanah yang di hakinya. Tanah adat bagi masyarakat adat adalah merupakan Wilayah tempat tinggal, dimana masyarakat adat hidup, dimana mereka dimakamkan, dimana mereka bertani untuk mempertahankan hidup mereka tiap hari dengan sumber daya alam yang ada di atas tanah masyarakat adat.

Pada umunya tanah-tanah di daerah Ambon Lease adalah tanah adat yang tunduk kepada dan juga dikuasai oleh petuanan ( beschikkingsrecht) dari desa atau negeri yang bersangkutan. Tanahtanah adat ini dapat disebut juga tanah ulayat dan sebutan untuk daerah Ambon dengan hak petuanan dan di golongkan

Disertasi, Program Pascasarjana, Universitas Indonesia, Jakarta, h. 86

10 Cooley, Frank L. (1987). Mimbar dan Takhta, cetakan pertama, Jakarta: Pustaka Sinar Harapan, h.107 
kepada tanah Negara yang tidak bebas (niet vrijlandsdomein).

Hak petuanan dari suatu Negeri di bagian daratan tidak hanya mengenai tanahnya saja, tetapi juga meliputi hutan, sungai dan segala hasilnya. Karena daerah Ambon Lease merupakan suatu daerah kepulauan, maka wilayah petuanan juga meliputi perairan sepanjang pantai yang didepannya sampai ke batas air putih dimana kita masih bisa melihat dasar lautnya, dalam perkembangan kemudian sebagian dari tanah petuanan itu lepas dari kekuasaan dan pengaturan langsung dari hak petuanan negeri-negeri yang bersangkutan, karena pada tanah-tanah tersebut telah muncul hak-hak yang bersifat perorangan atau hak-hak lainnya yang lebih kuat dari hak petuanan. ${ }^{12}$

Perspektif pertanahan, pada awal masa kolonial politik pertanahan yang destruktif belum dirasakan oleh masyarakat pribumi, karena saat itu bangsa Barat lebih berkonsentrasi pada upaya perdagangan rempah-rempah 13 Setelah berjalan beberapa dekade, lama kelamaan, para pedagang dari bangsa barat tersebut melakukan campur tangan ( intervensi ) pada sektor politik. Salah satu akibatnya, terbentuklah Pemerintah Hindia Belanda. Selama pemerintahan colonial Hindia Belanda, tanah milik masyarakat Indonesia di rampas dan di gunakan untuk kepentingan pemerintah. Saat itu politik hukum pertanahan sangat tidak adil, karena semua ketentuan hukum hanya di tujukan untuk keuntungan dan membela kepentingan pemerintah. Akibatnya di nusantara terjadi proses penguasaan tanah yang mengarah pada model kapitalisme pertanahan. Hal tersebut juga terjadi pada masa pendudukan tentara Jepang di Indonesia, karena secara substansial, antara

11 Effendi, Ziwar. (1987). Hukum Adat Ambon-Lease, Jakarta: Pradnya Paramita, h.. 91.

12 Ibid

13 Ibid.

14 Alting,Husen (2010). Dinamika Hukum Dalam perlindungan Hak Masyarakat Hukum pemerintahan Hindia Belanda dan pendudukan Bala tentara jepang samasama berakar pada ide imperialisme. ${ }^{14}$

Dari apa yang sudah di uraikan di atas mengenai jaman kolonial yang masuk ke belahan nusantara termasuk di Maluku, di sini ada perbedaan prinsipil yang khususnya mengenai penguasaan dan pemilikan tanah adat di jaman kolonial adanya perbedaan ini di lihat dari penguasaan yang di lakukan oleh pemerintahan belanda terhadap tanahtanah petuanan di Maluku tidak semuanya di perlakukan sama.

Perkembangannya sejarah hukum agraria di Indonesia, dapat dibagi dalam dua periode yaitu ${ }^{15}$

1. Masa sebelum kemerdekaan dan sebelum tahun 1945, yaitu:

a. Masa sebelum Agrarische Wet tahun 1870.

b. Masa setelah Agrarische Wet tahun 1870 sampai Proklamasi Kemardekaan.

2. Masa kemerdekaan (sejak tahun 1945), yaitu:

a. Masa sebelum Undang-Undang Pokok Agraria pada tahun 1945 sampai tahun 1960.

b. Masa setelah Undang-Undang Pokok Agraria.

Setelah terbitnya Undang-Undang Nomor 5 Tahun 1960 tentang Ketentuan Dasar Pokok Agraria tanggal 24 September 1960. Indonesia yang pada masa Penjajahan Hindia Belanda, sejak tahun 1815, praktis Kondisi Hukum yang berlaku, khususnya hukum perdata sudah bersifat dualistis, di samping hukum adat yang merupakan hukum perdata bagi golongan.

Penduduk pribumi, maka bagi golongan penduduk jajahan Belanda

Adat Atas Tanah, (Masa lalu, Kini, dan Masa Mendatang ), Yogyakarta: Laksbang Pressindo, h. 3.

${ }^{15}$ Daliyo, JB. (2001). Hukum Agraria I, Jakarta: Prenhallindo, h. 16 
berlaku hukum perdata yang mereka bawa dari negara asalnya. ${ }^{16}$ Pada masa sebelum kemerdekaan, di mana terdapat masa sebelum Agrarische Wet, peraturan yang digunakan dituangkan pemerintah jajahan di Hindia Belanda dalam bentuk Wet yang dikenal dengan RR (Regerings-Reglement) tahun 1855 (S.1855-2). .Semula RR tersebut terdiri dari tiga (3) ayat, selanjutnya dengan tambahan lima (5) ayat oleh AW (Agrarische Wet), Pasal 62 RR kemudian menjadi Pasal 51 IS (Indische Staatsregeling).

Adalah penting untuk mencari dasar hukum berlakunya hukum adat di zaman Hindia Belanda, tetapi yang selalu dihubungkan dengan pembicaraan tentang hukum adat ialah RR (Regerings Reglement) 1854, yaitu Pasal 75 (tujuh puluh lima) yang terjemahannya adalah sebagai berikut:

(1) Sepanjang mengenai golongan Eropa, pemberian keadilan dalam bidang keperdataan, begitu juga dalam bidang hukum pidana didasarkan kepada verordeningverordening umum, yang sejauh mungkin bersamaan bunyinya dengan Undang-Undang yang berlaku di Negeri Belanda.

(2) Gubernur Jenderal berhak untuk mengatakan berlaku aturan-aturan yang dipandang pantas, dari verordening-verordening tersebut bagi golongan Indonesia, ataupun bagi bagian-bagian dari golongan itu, kalau perlu aturan-aturan tersebut boleh diubah.

(3) Kecuali dalam hal pernyataan berlaku tersebut ataupun dalam hal orang Indonesia telah dengan sukarela tunduk kepada hukum perdata Eropa, oleh para Hakim untuk Indonesia dipergunakan 1. Undang-Undang Agama, 2 Golongan Indonesia, 3. Kebiasaan-

16 Ibid

17 Mahadi, (1991). Uraian Singkat tentang hukum adat sejak Regelings Reglemen Tahun 1854, Bandung: h. 1. kebiasaan Golongan Indonesia, sepanjang hal-hal 1, 2, 3 tidak bertentangan dengan asas-asas yang diakui umum tentang kepatuhan dan keadilan.

(4) Dalam memberikan keadilan kepada golongan Indonesia, para hakim mengambil asas-asas umum dari hukum perdata Eropa sebagai pedoman, manakala mereka harus memutus perkara, yang tidak diatur dalam Undang-Undang Agama, lembaga-lembaga dan Adat Kebiasaan Indonesia tersebut di atas. $^{17}$

Hukum Agraria Kolonial itu harus diganti dengan Hukum Agraria Nasional yang dibuat oleh pembentukan Undangundang nasional Indonesia, di buat dan disusun dalam bahasa Indonesia. Dengan di bentuknya UUPA oleh DPR-GR bersama presiden yang disususn dalam bahasa Indonesia serta berlaku dalam wilayah Indonesia, maka UUPA dalam hal ini mempunyai sifat nasional formil. ${ }^{18}$

Mengenai segi materiilnya, hukum agraria yang baru harus bersifaf nasioanal pula, artinya tujuan, asas-asas dan isinya harus sesuai dengan kepentingan nasional. Dalam hal ini, UUPA menyatakan pula dalam konsiderannya di bawah kata berpendapat bahwa hukum agraria yang baru harus ${ }^{19}$ :

a. Member kemungkinan supaya bumi, air, dan ruang angkasa dapat mencapai fungsinya dalam membangun masyarakat yang adil dan makmur;

b. Sesuai dengan kepentingan rakya Indonesia

c. Memenuhi pula keperluan rakyat Indonesia menurut permintaan zaman dalam soal agrarian;

d. Mewujudkan penjelmaan dari pancasila sebagai asas kerohanian

18 Muchisin, H. dkk, (2010). Hukum Agraria Indonesia Dalam Perspektif Sejarah, Bandung: Refika Aditama, h. 49.

19 Ibid. h. 49-50. 
Negara dan cita-cita bangsa seperti tercantum dalam pembukaan UUD'1945

e. Merupakan pelaksanaan dari Dekrit Presiden 5 Juli 1959 dan

f. Manifesto politik (GBHN,red)

g. Melaksanakan pula ketentuan pasal 33 UUD 1945.

Dari penjelasan tersebut di atas, maka dapat dikatakan bahwa terhadap upaya yang di lakukan oleh pemerintah dalam mewujudkan Undang-undang Agraria Nasional adalah untuk menjamin kepastian didalam peraturan perundangundangan agar tidak terjadi dualisme hukum, seperti kita ketahui bahwa terbentuknya UUPA didasarkan pada Hakhak adat dan hak-hak barat.

Eksistensi tanah-tanah adat di jaman kemerdekaan masih tetap di akui eksistensinya sepanjang tidak bertentangan dengan peraturan perundang-undangan yang berlaku di Negara Republik Indonesia

\section{Hak Milik Atas Tanah.}

Timbulnya hak milik atas tanah yang akhirnya cenderung ke arah pemilikan individual terjadi melalui proses. Kesewenang-wenangan dapat terjadi selama proses penguasaan dan penggunaan hak atas tanah, termasuk hak atas memperoleh manfaat. Hasil guna atau kegunaan atas tanah yang sudah ada sejak dulu, turun temururn, selanjutnya mempunyai hak mengalihkan tanah tersebut kepada pihak lain dengan leluasa tanpa ada hambatan. Sedangkan pihak lain atau masyarakat tidak mau mengganggu hak-hak itu lagi, maka disitulah sebenarnya sudah terjadi proses permulaan timbul hak milik atas tanah.

Hak milik atas tanah yaitu hak yang dibatasi oleh hak komunal. Dalam arti bahwa hak dari anggota masyarakat (hak perseorangan) untuk menguasai secara penuh atas tanah. Sifat berkuasa sepenuhnya adalah penguasaan milik sendiri, seperti dalam arti menguasai rumah, ternak, dan benda lain miliknya. Namun demikian, tetap dibatasi oleh hakhak sebagai berikut.

a. Hak ulayat masyarakat hukum

b. Kepentingan-kepentingan lain yang memiliki tanah

c. Peraturan-peraturan/hukum adaat seperti kewajiban memberi izin ternak orang lain selama tidak dipagaari atau tidak dipergunakan.

Individu sebagai warga suatu masyarakat hukum mempunyai hak untuk:

a. Mengumpulkan hasil-hasil hutan, seperti rotan,kayu dan lain sebagainya

b. Memburu binatang liar yang hidup di wilayah kekuasaaan masyarakat hukum

c. Mengambil hasil pepohonan yang tumbuh liar

d. Membuka tanah dan mengerjakan tanah secara terus-menerus dan

e. Penguasaan tanah dan pengurusan tanah.

Bentuk dari hak milik atas tanah di Negeri Kairatu diperoleh dengan cara pemberian dari Negeri kepada seseorang untuk diperusah dan lama kelamaan akan menjadi hak milik dengan hak milik ini dapat di daftarkan untuk memiliki sertifikat sebagai alas hak yang sangat kuat untuk menjamin kepastian hukum, demikian juga di Negeri Kamariang apabila ada tanah-tanah yang sudah lepas dari campur tangan Pemerintah Negeri maka tanah tersebut dapat didaftarkan menjadi hak milik . Begitu juga pada Negeri Allang berdasarkan hasil wawancara dengan Bapak R.W. Sohilait Mantan Kepala Desa bahwa Tanah adat di Negeri Allang sudah didaftarkan sejak Tahun 1814. ( zaman kolonial Belanda ). Dimana daftar tanah Adat pada saat itu dinamakan " REGISTER DATI atau REGISTER TUA “jika diatas 1814 itu disebut SALINAN REGISTER DATI. Dimana Register Dati ini memuat semua nama kelompok masyarakat yang 
dihimpun menurut marga masing-masing. Dalam Register Dati itu tercantum namanama marga yang dipimpin oleh satu orang yang diangkat dari masing-masing marga dan dinamakan Kepala Dati. Dengan demikian Tanah adat atau Dati harus didaftarkan untuk menjamin kehidupan masayarakat yang lebih teratur dan harmonis.

Selanjutnya berdasarkan aturan adat bahwa Sesungguhnya Tanah dati tidak perlu didaftarkan di Badan Pertanahan Nasional (selanjunta disebut BPN), karena Tanah adat memiliki aturan yang sangat melekat dalam kehidupan masayarakat adat di Negeri Allang. Dimana Hak kepemilikan Tanah Dati/Adat itu diwariskan secara turun temurun di dalam keluarga Dati. Dan tidak dapat dipindah tangankan kepada orang lainatau dijual belikan. Selanjutnya Hasil wawancara kami dengan Bapak Yance Siwalette, beliau mengatakan bahwa Tanah Adat / Dati yang kami miliki sudah kami daftarkan ke Badan Pertanahan Nasional, karena pada saat itu kami ingin melindungi Tanah adat/Dati yang kami miliki sehingga kami daftar. Tetapi timbul pertentangan dalam keluarga kami, ada yang bilang Tanah Adat itu tidak boleh di daftarkan, tetapi menurut kami Tanah itu harus didaftarkan sehingga orang lain atau marga lain tidak bisa mengambil Tanah Adat/Dati yang kami miliki karena Badan Pertanahan Nasional sudah menerbitkan sertifikat Tanah.

Dari apa yang sudah diuraikan tersebut diatas maka dapat dikatakan bahwa perkembangan tanah-tanah adat dimasa kini lambat laun akan menjadi punah dikarenakan banyak masyarakat hukum adat mendaftarkan tanah mereka untuk melindungi dari pihak-pihak yang tidak bertanggungjawab dan untuk menjamin kepastian hukum.

Hak milik atas tanah dapat diperoleh dengan cara membuka tanah hutan,

20 Pide, A Suriyaman Mustari. (2014). Hukum Adat Dahulu, Kini Dan Akan Datang, Jakarta: Prenada Media Group, h. 54. mewaris tanah, pembelian ,pertukaran, hadiah, dan membuka tanah. Setiap warga masyarakat hukum mempunyai hak membuka hutan atas tanah belukar yang masih dalam lingkungan hak ulayat masyarakat hukum, dengan sepengetahuan kepala persekutuan ia memilih sebidang tanah, membuat, dan menepatkan tanda-tanda batas, yang dimaksud dengan mewarisi tanah adalah suatu tindakan yang dimaksudkan untuk pengoperan atau penerusan tanah generasi ke generasi berikuntnya.

Mewaris tanah terjadi sebagai akibat pengaruh hubungan hak masyarakat hukum dengan hak perseorangan, dimana hak masyarakat hukum menipis maka disitulah ahli waris dari pemilik tanah yang meninggal selalu mendapat hak milik atas tanah itu sebagai warisan. Demikian juga pada Negeri Kairatu, Negeri Kamariang dan Negeri Allang yang berhak untuk mewarisi tanah-tanah adat yaitu garis keturunan Pattrilineal

\section{Hak Komunal Ke Hak Individual}

Istilah komunal dikenal sebagai hak yang dimiliki secara turun temurun termasuk hak ulayat (hak Kolektif) atas yang para pendukung haknya adalah masyarakat persekutuan hukum adat bukan hak individu, dalam perkembangan masyarakat, hukum adat mengalamai perubahan karena adanya faktor-faktor yang sangat berpengaruh bahkan tidak bisa dipungkiri sebagai penyebabnya, dalam kenyataannya, hukum adat dengan hak komunal hak Kolektif) sebagai karakterristik masyarakat hukum adat sebagai suatu tatanan yang ditaati secara turun-temurun oleh kelompok masyarakat hukum adat yang mengarah pada proses akan hak-hak ulayatnya dengan sejumlah kriteria keberadaannya mengalami perubahan atau pergeseran disebabkan berbagai faktor. ${ }^{20}$ pengaruh utama ke arah 
perubahan bentuk menurut Ter Haar antara lain:

1. Karena keinginan untuk berdiri sendiri

2. Berkurangnya hasil hutan dan ketersediaan tanah

3. Konflik (permusuhan) antar kerabat

Berdasarkan pada hasil wawancara dengan Kepala Negeri Kairatu bahwa berkitan dengan tanah adat untuk negeri kairatu sendiri dikenal dengan penyebutan "Petuanan Negeri" yang mempunyai pengertian bahwa Salah satu hak milik adat yang dikuasai bersama oleh suatu masyarakat secara kolektif yang mencakup suatu kesatuan wilayah dikuasai secara bersama-sama. Untuk perkembangan Petuanan Negeri tersebut Tidak dapat diperjual belikan dalam keadaan apapaun itu. Yang terjadi jual beli adalah tanah yang sudah diberikan oleh Negeri untuk diperusah secara bertahuntahun dan lama kelamaan dapat dijadikan hak milik. Demikian juga dengan Tanah adat yang berada di kamariang bahwa penyebutan untuk tanah adat tersebut dengan tanah Negeri yang mana tanah tersebut juga tidak dapat diperjual belikan , yang dapat di perjual belikan adalah tanah adat yang sudah diserahkan oleh Negeri kepada Mata rumah atau secara individu dengan proses pelepasan hak .

Selain Tanah Petuanan dan Tanah Negeri yang terdapat di Kairatu dan Kamariang, hasil wawancara juga dilakukan di Negeri Allang yang Berkaitan dengan Tanah Adat yaitu Tanah Dati, Tanah Adat/Dati berasal dari kata DULANG yang artinya meja makan dari keluarga. DULANG ini dia bisa ditempati oleh keturunan garis lurus. Garis lurus ini, dia juga bisa diberikan kepada yang bukan garis lurus apabila disetujui oleh anakanak Dati yang ada di Dulang ini. Itupun terbatas, mungkin untuk rumah atau dusun satu (1) atau dua (2) potong. Misalnya ada serorang saudara perempuan yang belum nikah, itu bisa diberikan dusun atau tanah untuk rumah, misalnya juga ada marga lain yang duduk sama-sama dengan anak Dati pada satu DULANG maka itu disebut Anak TULUNG Dati yang artinya anak yang diakui sebagai keluarga maka dari itu bisa diberikan Tanah Adat/Dati kepada anak-anak atau Tulung dati tersebut, sedangkan Pemberian Tanah yang bukan tercatat dalam keluarga itu disebut SANIWU artinya dalam keluarga yang bersangkutan tidak tercatat tapi itu merupakan suatu peringatan bahwa Tanah Adat/Dati sudah diberikan kepada dia dan itu tidak bisa diganggu oleh yang lain. Selain itu juga ada cara untuk mendapatkan Tanah Dati yang lain waktu Dulu, yaitu bisa dengan Cara membeli Tanah Dati itupun atas persetujuan masing-masing anak Dati. Ada juga Seseorang yang dia ingin memiliki Tanah di Negeri Allang, itu dia harus minta kepada Perangkat Adat ketika ada RAPAT NEGERI, persyaratan utama yang ia harus brikan dalam RAPAT NEGERI ITU ADALAH dia harus menaikan TAMPA SIRIH di BAILEO, setelah dia menaikan TAMPA SIRIH itu baru dia akan mendapatkan Tanah entah itu Tanah adat/Dati yang diminta. Pada saat mulai terjadinya pembagian tanah adat di negeri Allang, sejalan dengan perkembangan penduduk, dimana dalam kehidupan masayakat pada saat itu dibagi bagi dalam beberapa kelompok atau segmen menurut atau sesuai Marga dan berdasarkan garis atau keturanan laki-laki ( patrinial) Dimana masing-masing Marga mendapatkan Hak waris, baik itu untuk pemukiman atau rumah, maupun Tanah untuk Lahan usaha perkebunan, dalam perkembangan kehidupan masayarakat pada saat itu, timbulah ide unutk membuat atau menetapkan aturan-aturan adat dalam hal kepemilikan Tanah-tanah Adat tersebut. Sehingga dalam tradisi yang terjadi hingga saat ini, masing-masing marga memiliki warisan tanah adat secara turun temurun. Tanah Adat/Dati harus dijaga masayarakat Adat, karena itu merupakan TITAH atau aturan dari Raja Negeri Allang. 
Proses untuk seorang atau anggota masyarakat hukum adat atau masyarakat hukum adat untuk memperoleh atau menguasai wilayah petuanannya dapat dilihat dalam penggolongan sebagai berikut; ${ }^{21}$

a) Bahwa tanah petuanannya selalu harus dibedakan kedalam tiga bagian pokok yaitu: (1). Bagian yang dinamakan ,tanah kampung atau negerie (2).Bagian yang dinamakan „tanah hutan, atau ewang (ewang:semak belukar), (3). Bagian yang dinamakan ,tanah persediaan ${ }^{\text {ee }}$.

b) Bahwa hak petuanan merupakan dasar segala macam ,hak perorangan atas tanah yang ada diatasnya, dan karena hak-hak perorangan yang membebaninya tetap bergantung dan tunduk pada hak petuanan.

c) Bahwa hak-hak perorangan atas tanah yang ada diatas hak petuanan itu, kwalitas ikatannya dengan yang mempunyai hak, digantungkan kepada bukti nyata identitas dari pemanfaatan dan pemeliharaan tanahnya.

d) Bahwa pemakaian dan pemanfaatan tanah petuanan atas dasar hak perorangan yang ada pada seseoarang, tunduk kepada asas kepatutan atau kepantasan dalam menggunakan dan mengambil yang didasarkan atas penggunaan hak perorangan yang bersangkutan. Bahwa melampaui batas ukuran dalam memakai dan mengambil manfaat tanah atas dasar hak perorangan oleh yang bersangkutan akan mendapat tegoran dari masyarakatnya, dan selanjutanya yang bersangkutan akan dikenakan hukuman berupa kewajiban ganti rugi kepada masyarakat.

Dalam memanfaatkan dan mengolah tanah petuanan dalam hubungannya dengan hak individu , maka pada mulanya untuk memperoleh hak ini, diperoleh dengan adanya pertalian darah dengan mata rumah tententu dan atau dihubungkan dengan persyaratan lainnya yaitu membayar pajak serta telah menjalankan wajib kerja. Berdasarkan aturan , hak untuk mengolah atau membuka tanah dalam dusun negeri adalah hak istimewa yang dimiliki anak negeri dan untuk mereka dapat menyampaikan keinginannya kepada pemerintah negeri. Keinginan atau permohonan tersebut diajukan secara lisan atau tertulis dan untuk itu saniri negeri akan mengeluarkan atau memberikan akte. Dengan akte ini pemohon memperoleh hak pakai atas tanah dan bilamana tanah tersebut ditanami terus-menerus, misalnya kebun yang ditanami dengan tanaman umur panjang, maka lambat laun status tanah itu bukan lagi sebagai tanah negeri tetapi telah menjadi tanah pusaka oleh karena pengolahannya telah dialihkan pada anak cucu pemohon.

Dari kenyataan-kenyataan inilah yang menjadi penyebab untuk sebuah kemungkinan terjadi pergeseran dari yang sifatnya komunal menjadi individualistis (hak kolektif mengarah ke Individual) namun harus diketahui bahwa disamping hak perorangan atas tanah tidak bersifat multlak, selalu ada batasnya yakni kepentingan orang lain (fungsi sosial), dengan tetap memeberikan tempat dan penghormatan hak perseorangan

\section{Perlindungan Hukum Terhadap Masyarakat Hukum Adat.}

Pada dasarnya teori perlindungan hukum merupakan teori yang berkaitan dengan pelayanan kepada masyarakat. Roscou Pound mengemukakan hukum merupakan alat rekayasa sosial. Kepentingan manusia, adalah

21 Koesno, H. Moh. Kapita Selekta Hukum Adat, Suatu Pemikiran Baru, Jakarta: Varia Peradilan Ikatan Hukum Indonesia, h. 126-127 
tuntutan yang dilindungi dan dipenuhi manusia dalam bidang hukum.

Kepentingan manusia yang dilindungi hukum dapat dibagi menjadi tiga macam, yang meliputi ${ }^{22}$ :

1. Kepentingan umum

2. Kepentingan masyarakat

3. Kepentingan Individu

Dari penjelasan singkat yang diuraiakn diatas dibutuhkan ekstra kerja bagi pemerintah dalam menghadapi masalah yang terjadi dalam masyarakat berkaitan dengan perlindungan masyarakat hukum adat. Disini bukan saja masyarakat pada umumnya akan tetapi jika kita lihat sebagai subjek hukum maka masyarakat hukum adat merupakan subjek yang harus dilindungi oleh pemerintah, kita ketahui bahwa banyak atutan perundang-undangan yang sudah dibuat untuk mengakui masyarakat hukum adat dan pada saat adanya pengakuan tersebut secara konkrit bahwa masyarakat hukum adat harus dilindungi hak-haknya.

Salah satu dari sekian peraturan Perundang-undangan yang menyatakan pengakuan tersebut adalah dalam Undangundang Dasar Negara Republik Indonesia Tahun 1945 (selanjutnya disebut UUD NRI Tahun 1945) Pasal 18B ayat (2) , yang menyatakan bahwa :

Negara mengakui dan menghormati kesatuan-kesatuan masyarakat hukum adat serta hak-hak tradisonalnya sepanjang masih hidup dan sesuai dengan perkembangan masyarakat dan prinsip Negara Kesatuan Republik Indonesia, yang diatur dalam undang-undang.

Pengakuan. ${ }^{23}$ secara terminologi berarti proses, cara, perbuatan mengakui, sedangkan kata mengakui. ${ }^{24}$ berarti menyatakan berhak. Menurut Abu daud Busroh ${ }^{25}$.

\section{pengakuan (Erkenning/Recognisi)}

22. Lili Rasyidi, Filsafat Hukum, Remadja Karya, Bandung, 1988, Hal. 228 Pengakuan

23. Http / Kamusbahsaindonesia. Org /

${ }^{24}$. Ibid ada (dua) macam, yaitu: Pengakuan de facto (sementara), yaitu pengakuan yang sifatnya sementara terhadap munculnya atau terbentuknya suatu Negara baru karena kenyataannya Negara baru tersebut secara kenyataan ada tetapi apakah prosedurnya melalui hukum masih diperdebatkan sehingga perlu diteliti lebih lanjut.

Menurut Moh Kusnardi dan Bintan Saragih sebagaimana dikutip oleh Husein Alting. ${ }^{26}$ bahwa pengakuan de facto bersifat sementara yang ditujukan kepada kenyataan - kenyataan mengenai kedudukan pemerintahan Negara baru tersebut, apakah ia didukung oleh rakyatnya dan apakah pemerintahannya efektif yang menyebabakan kedudukannya stabil. Jika kemudian dapat dipertahankan keadaan tersebut dan terus bertambah maju, maka pengakuan de facto akan berubah dengan sendirinya menjadi pengakuan de jure.

Berdasarkan hal tersebut, maka secara de facto keberadaan kesatuan masyarakat hukum adat atau desa diakui keberadaannya karena di dasarkan pada kenyataan bahwa sistem adatnya masih tetap ada, dipelihara dan didukung oleh rakyatnya, sehingga masih tetap di berlaku di dalam kehidupan kesatuan masyarakat adat atau desa. Pengakuan de jure (Pengakuan Yuridis), yaitu pengakuan yang seluas-luasnya dan bersifat tetap terhadap munculnya atau timbulnya atau terbentuknya suatu Negara, dikarenakan terbentuknya Negara baru adalah berdasarkan hukum.

Sementara itu, menurut Husein Alting. ${ }^{27}$ bahwa pengakuan de Jure adalah pengakuan suatu Negara terhadap Negara lain yang diikuti dengan tindakantindakan hukum tertentu, misalnya pembukaan hubungan diplomatik dan kemampuan untuk melakukan perjanjian

25. Abu Daud Busroh, Ilmu Negara, Bumi Aksara, Jakrta, 2009. Hal. 46

26 Alting,Husein. Op.it. h. 63.

27 Ibid 
dengan Negara lain. Berdasarkan konsep tersebut maka pegakuan secara de Jure (yuridis) terhadap kesatuan masyarakat hukum adat terjadi apabila keberadaan kesatuan masyarakat hukum adat masih tetap dipertahankan nilai-nilai adatnya dan tetap dijaga dan dipelahara oleh masyarakat pendukungnya, sehingga Negara mengakuinya dan mengaturnya dalam ketentuan peraturan perundangundangan yang berlaku atau diatur dan dijamin dalam hukum positif.

Berdasarkan teori tersebut, jika dikaitkan dengan konteks pengakuan terhadap keberadaan kesatuan masyarakat hukum adat, maka dapat diketahui bahwa Pengakuan desa secara de facto merujuk pada adanya pengakuan terhadap kenyataan sejarah sampai sekarang mengenai keberadaan kesatuan masyarakat hukum adat di NKRI yang masih tetap ada. Sedangkan pengakuan secara de jure merujuk pada pengakuan hukum terhadap keberadaan desa di NKRI.mPengakuan secara de facto dapat dilihat dari adanya pengakuan terhadap keberagaman kesatuan masyarakat hukum adat di Indonesia dalam konteks desa. Masyarakat Indonesia berdomisili pada ribuan pulau besar dan kecil di wilayah Republik Indonesia berdasarkan hukum adatnya masing-masing.

Dari penjelasan-penjelasan tersebut ada tiga hasil temuan yang disajikan oleh Husein Alting ${ }^{28}$, yaitu :

1. Pengakuan dan perlindungan hak atas tanah masyarakat hukum adat dipengaruhi oleh politik hukum pemerintah. Sebelum masuknya penjajah, tanah dikuasai oleh komunal masyarakat. Setelah berlakunya UUPA, pengakuan hak atas tanah adat diakui dengan persyaratan berlapis, yakni berkaitan dengan syarat-syarat keberadaan dan pelaksanaannya

2. Konstitusi maupun sebagian perundang-undang telah memberikan

${ }^{28}$ Alting, Husein. (2006). "Pengakuan Dan Perlindungan Hak Masyarakat Atas Tanah Di Maluku Utara Perpektif Dinamika Hukum Di Era pengakuan dan perlindungan hak atas tanah masyarakat hukum adat akibat dari tuntutan masyarakat, namun pada tataran lokal maupun pusat; dan

3. Belum adanya jaminan perlindungan hak masyarakat hukum adat, bahkan menjadi korban dari kepentingan pemerintah dan perusahaan dalam mengeksploitasi sumber daya alam yang dimilikinya

\section{P E N U T U P}

Konsep tanah adat di Ambon merupakan prinsip pokok dalam pandangan hidup masyarakat hukum adat. Pandangan hidup dimaknai menjadi sesuatu yang bermakna dan menjadi dasar pokok dalam pandangan hidup masyarakat Ambon yang bersumber pada tradisi dan kebiasaan yang masih dipatuhi dalam hubungan dengan prinsip hak dan kewajiban, prinsip penggunaan, prinsip penguasaan tanah serta prinsip pemilikan tanah. Dengan demikian bahwa hakikat dari pandangan hidup ini adalah pada arti dan makna antara manusia dengan tanahnya. Tanah diciptakan untuk dikuasai dan dikelolah oleh manusia. Dengan perkembangan yang semakin pesat, kebutuhan akan tanah adat semakin dibutuhan untuk kepentingan sosial atau untuk kepentingan umum bahkan untuk kepentingan pribadi sehingga tanah-tanah adat yang statusnya tanah adat dapat berubah status menjadi hak milik.

\section{DAFTAR PUSTAKA}

Alting, Husen. (2010). Dinamika Hukum

Dalam perlindungan Hak Masyarakat Hukum Adat Atas Tanah, ( Masa lalu, Kini, dan Masa

Otonomi Daerah", Disertasi Fakultas Hukum Pascasarjana Universitas Brawijaya, h. 525-532 
mendatang ). Yogyakarta: Laksbang Pressindo.

Busroh, Abu Daud. (2009). Ilmu Negara, Jakrta: Bumi Aksara.

Cooley, Frank L. (1987). Mimbar dan Takhta, Cetakan Pertama, Jakarta: Pustaka Sinar Harapan.

Daliyo, JB. (2001) Hukum Agraria I, Jakarta: Prenhallindo.

Effendi, Ziwar. (1987). Hukum Adat Ambon-Lease, Jakarta, Pradnya Paramita.

Koesnoe, H.Moh. (2002). Kapita Selekta Hukum Adat Suatu Pemikiran Baru, Jakarta: Varia Peradilan, IKAHI.

Mahadi. (1991) Uraian Singkat tentang hukum adat sejak Regelings Reglemen Tahun 1854, Bandung.

. Muchisin, H, dkk. (2010). Hukum Agraria Indonesia Dalam Perspektif Sejarah, Bandung: Refika Aditama,

Pide, A Suriyaman Mustari. (2014). Hukum Adat Dahulu, Kini Dan Akan Datang, Jakarta: Prenada Media Group.

Rasyidi, Lili. (1988). Filsafat Hukum, Bandung: Remadja Karya.

Rato, Dominikus. (2011). Hukum Adat (Suatu Pengantar Singkat Memahami Hukum Adat Di Indonesia), Yogjakarta: Laksbang Pressindo.

Soeprapto, R. 1966.Undang-Undang Agraria Dalam Praktek, Jakarta: Mitra Sari.

Samosir, Djamanat . (2013). Hukum Adat Eksistensi Dalam Dinamika Perkembangan Hukum Di Indonesia, Cetakan I, Bandung: Nuansa Aulia.

\section{Lain-Lain}

Alting, Husein. (2006). "Pengakuan Dan Perlindungan Hak Masyarakat Atas Tanah Di Maluku Utara Perpektif Dinamika Hukum Di Era Otonomi Daerah", Disertasi, Universitas Brawijaya.
Kriekhoff, Valerine Jaqueline Leonora. (1991). Kedudukan tanah dati sebagai tanah adat di Maluku Tengah suatu kajian dengan memanfaatkan pendekatan Antropologi Hukum, Disertasi, Universitas Indonesia,

Muhibbin, Moh. (2011). Penguasaan atas tanah timbul ( aanslibbing ) oleh masyarakat dalam perspektif hukum Agraria Nasional, Ringkasan Disertasi, Universitas Brawijaya.

Http/Kamusbahsaindonesia.Org/Pengaku an. 